\title{
Biodegradation of anionic surfactants by isolated bacteria from activated sludge
}

\author{
${ }^{1 *}$ F. Hosseini, ${ }^{1}$ F. Malekzadeh, ${ }^{2} N$. Amirmozafari, ${ }^{3}$ N. Ghaemi \\ ${ }^{1}$ Department of Microbiology, Science and Research Campus, Islamic Azad University, Tehran, Iran \\ ${ }^{2}$ Department of Microbiology, Iran University of Medical Sciences, Tehran, Iran \\ ${ }^{3}$ Department of Biotechnology, Tehran University, Tehran, Iran
}

Received 20 August 2006; revised 14 September 2006; accepted 18 November 2006; available online 1 January 2007

\begin{abstract}
Sodium dodecyl sulphate, (SDS) is an anionic surfactant that widely used all over the world. They will eventually end-up and accumulate in household or industrial sewage. Due to their high foaming capabilities, which can cause numerous problems in sewage treatment facilities as well as direct toxic effects on many different organisms in ecosystem; they are generally considered as serious pollutants. In this survey, two different bacteria were isolated from Tehran municipal activated sludge. Biochemical tests as well as 16S rRNA gene sequencing for identification have been applied. After experiments to optimize the $\mathrm{pH}$ and temperature for growth of the two bacterial isolates, the extent of SDS utilization was evaluated by HPLC method. Two bacterial isolates show which ability to rapidly and actively degrade SDS upon using it as their sole source of carbon. The identification tests have indicated the two isolates to be Acinetobacter johnsoni and Pseudomonas beteli. The Pseudomonas beteli and Acinetobacter johnsoni isolates were able to degrade $97.2 \%$ and $96.4 \%$ of the original SDS levels after 10 days of growth; respectively. Mixed culture of the two isolates did not significantly increase SDS utilization, (97.6\%). In conclusion, the results of this study suggest that growth of simple bacteria such as Acinetobacter or Pseudomonas in household and industrial sewage can be costeffective method anionic surfactants elimination.
\end{abstract}

Key word: Sodium dodecyl sulphate SDS), biodegradation, activated sludge, anionic surfactant

\section{INTRODUCTION}

Surfactants, due to their favorable physicochemical properties are extensively used in many fields of technology and research, i.e. in pharmacy, in cosmetics, textile industry, agriculture, biotechnology (Sales, et al., 1999). After use large quantities of surfactants and their derivatives are released to aquatic and /or terrestrial environment. These compounds can act on biological wastewater treatment processes and cause problems in sewage aeration and treatment facilities due to their high foaming, lower oxygenation potentials and making death of waterborne organisms (Eichhorn, et al., 2002). Anionic surfactants such as sodium dodecyl sulphate (SDS) have been use for about 40 years (Lauer, et al., 1996). SDS, in particular, is an essential component of shampoos and foaming agent for toothpaste. Principal criterion for the ecological behavior of surfactants is their biodegradability (Cain, et al., 1981). Biodegradation is most often performed

*Corresponding author, Email: hofa1343@yahoo.com Tel: +9821 2264 1842; Fax: +9821 22666016 by soil or aquatic microorganisms and leads to generation of water and carbon dioxide gas (Schleheck, et al., 2000). The molecular structure of SDS is composed of three units, (1) A hydrocarbon chain, $\left(\mathrm{C}_{11}\right.$ $\mathrm{C}_{14}$; (2) A benzene ring attached to the chain; and, (3) A sulphate group attached to the ring (Schleheck, et al., 2003). In nature and under standard at very low rate (Juker, et al., 1994). In this survey, SDS degrading bacteria were isolated and identified by 16S RNA sequencing from activated sludge of several locations in Tehran. Their single as well as mixed culture surfactant degradation capability in aerobic growth was measured by HPLC method.

\section{MATERIALS AND METHODS}

Bacterial isolation

Activated sludge samples obtained from Gheitarihe sewage treatment company in Tehran was subjected, (5\%) to $500 \mathrm{~mL}$ basal salt medium, $\left(\mathrm{KH}_{2} \mathrm{PO}_{4} 3.5 \mathrm{~g}\right.$, $\mathrm{K}_{2} \mathrm{HPO}_{4} 1.5 \mathrm{~g}, \mathrm{NH}_{4} \mathrm{Cl} 0.5 \mathrm{~g}, \mathrm{NaCl} 0.5 \mathrm{~g}, \mathrm{Na}_{2} \mathrm{SO}_{4} 0.14 \mathrm{~g}$ 
, $\mathrm{MgCl}_{2} \cdot 6 \mathrm{H}_{2} \mathrm{O} 0.15 \mathrm{~g}$, dissolved in $1 \mathrm{~L}$ of distilled water and the final $\mathrm{pH}$ adjusted to 7.1) and containing 1.5 $\mathrm{mM}$ sodium dodecyl sulphate $\left(\mathrm{C}_{12} \mathrm{H}_{25} \mathrm{OSO}_{3} \mathrm{Na}\right)$. Its molecular weight is $288 \mathrm{~g} / \mathrm{moL}$.Critical micellar concentration $(\mathrm{cmc}$ ) is equal to $2310 \mathrm{mg} / \mathrm{L}$ The inoculated media were incubated at room temperature with constant Shaking, (150 rpm). After no foams were visible during growth, (due to surfactants utilization), the liquid culture was transferred to solidified, (1\% agar) basal salt medium with $1.5 \mathrm{mM}$ SDS in culture plates. Following three subcultures on the solid media, two different bacterial colonies were isolated and identified. The growth curve of the two bacterial strains, (A and B) in the surfactants containing liquid media as well as $\mathrm{pH}$ and growth temperature optima were subsequently determined.

\section{Culture}

Each strain was grown, either as single or mixed culture, after an adaptation step in nutrient broth was containing SDS, in basal salt medium, (BSM) containing $1.5 \mathrm{mM}$ SDS as the sole source of carbon. Incubation was performed at optimum $\mathrm{pH}$ and temperature with shaking, (150 rpm) for 12 days. Culture samples were collected and analyzed for SDS utilization after 1, 3, 5, 7 and 10 days of growth.

\section{Surfactant degradation}

HPLC with a C-18 column, (18 cm length and 4 $\mathrm{mm}$ width) using an isocratic mobile phase gradient of acetonitrile-water, (80-20) was conducted at a flow rate $1 \mathrm{ml} / \mathrm{min}$. Eluent absorption was detected with a UV spectrophotometer at $220 \mathrm{~nm}$.

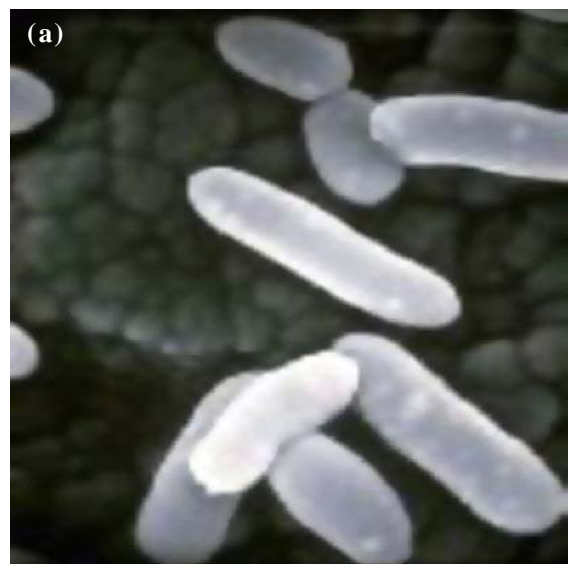

\section{Bacterial identification}

Initial identification schemes were performed with biochemical tests as suggested by the Bergeys Manual of Systematic Bacteriology. For final and specific identification, 16S rRNA sequencing was performed after PCR with specific primers.

\section{RESULTS}

The two bacteria, (A and B) isolated from activated sludge grow well in BSM media with SDS as their sole carbon source. The optimum $\mathrm{pH}$ values for the growth of $A$ and $B$ strains in the basic medium at 30ÚC were 7.4 and 8.0, respectively. Based on morphologic and biochemical characteristics, (Fig.1 and Table 1), as well as 16S rRNA gene sequencing, with the nearest phylogenic relatedness (99\% homology), the A and B strains are members of Pseudomonas betelli and Acinetobacter johnsoni strains, respectively. Fig. 1 shows electron micrographs of the two bacteria in activated growth. HPLC analysis indicated that A strain had the highest surfactant degrading potential, (Table 2 ). The B strain was able to decrease SDS level in the growth media from an original of $522 \mathrm{mg} / \mathrm{L}$ to the extent of $93.6 \%$ within 5 days; whereas, the other strain did so to the extent of $84.6 \%$, (Fig. 2 and Table 2). However, following 10 days of incubation, A strain showed greater degradation, (97.2\%) potential relative to the B strain, (96.4\%). The highest peak of SDS degradation occurred during the logarithmic phase of bacterial growth (Figs. 3 and 4). Co-culture of the two strain did not significally increase the degradation potential, (97.6\%) SDS degradation after 10 days of growth) relative to single bacterial growth, (Table2).

Fig . 1: Electron micrographs of A strain (a), and B strain (b) 
Int. J. Environ. Sci. Tech., 4 (1): 127-132, 2007
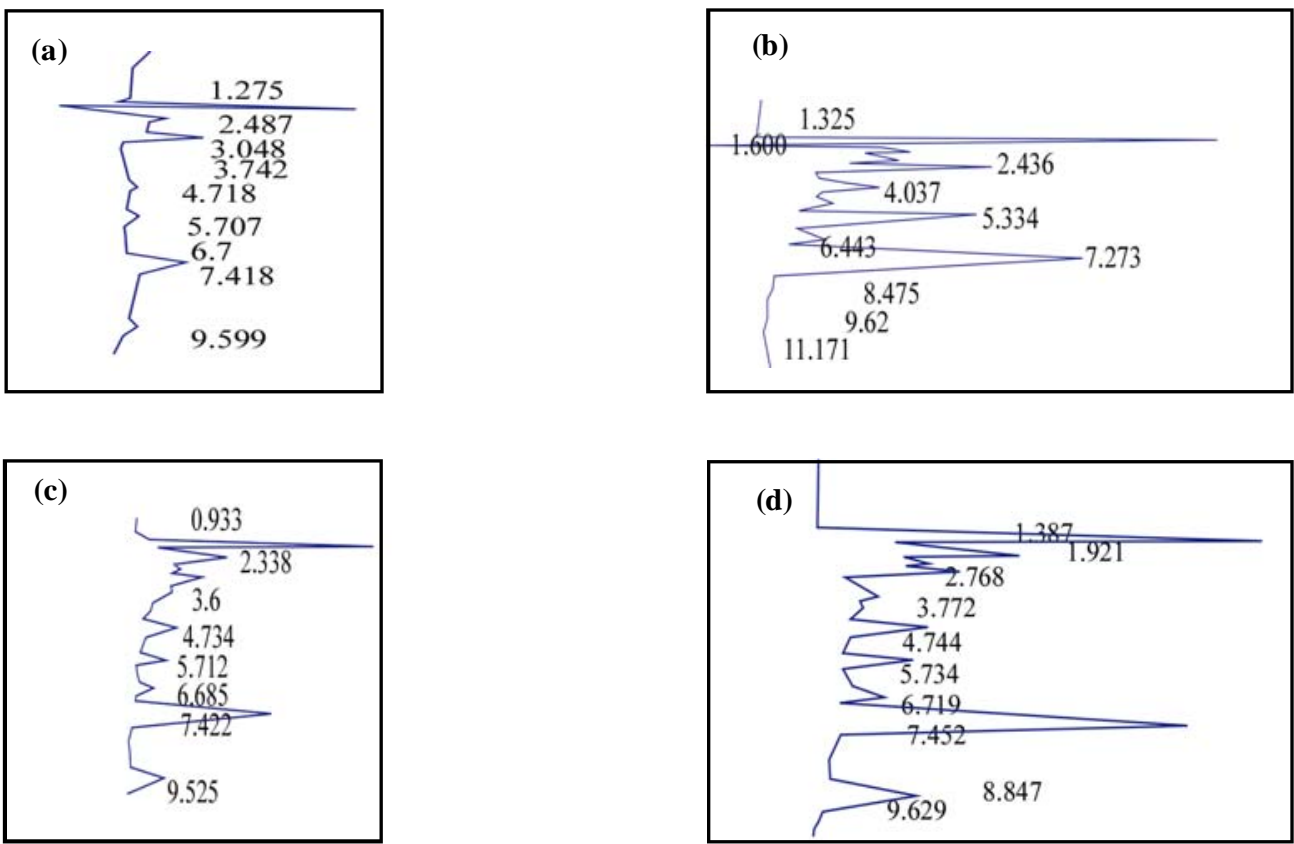

Fig. 2: HPLC analysis of SDS degradation in, (a) A strain at 1 day, (b) A strain at 10 days, (c) B strain at 1 day, (d) B strain at 10 days of incubation

Table 1: Morphologic and biochemical characteristics of isolated strains

\begin{tabular}{|c|c|c|}
\hline Tests & $\mathrm{A}$ & $\mathrm{B}$ \\
\hline Gram staining & $\begin{array}{l}\text { Slightly curved rods } 0.5-1.0 \mu \mathrm{m} \text { in diameter, } \\
1.5-5.0 \mu \mathrm{m} \text { in length, Gram-negative }\end{array}$ & $\begin{array}{l}\text { Straight rods } 0.9-1.6 \mu \mathrm{m} \text { in diameter, } 1.5-2.5 \\
\mu \mathrm{m} \text { in length, Gram-negative }\end{array}$ \\
\hline Motility & + & + \\
\hline Capsule & + & + \\
\hline Oxidase & + & - \\
\hline Catalase & + & + \\
\hline \multicolumn{3}{|l|}{ Growth in: } \\
\hline $4^{\circ} \mathrm{C}$ & + & - \\
\hline $42^{\circ} \mathrm{C}$ & + & - \\
\hline Haemolysis & + & - \\
\hline Citrate & + & + \\
\hline Acid from glucose & - & - \\
\hline Nitrate reduction & + & + \\
\hline Tryptophanase & - & - \\
\hline Arginin dihydrolase & + & + \\
\hline Gelatinase & + & - \\
\hline Lysine hydrogenase & - & - \\
\hline Pigment production & - & - \\
\hline \multicolumn{3}{|l|}{ Utilization of: } \\
\hline D-Lactose & - & + \\
\hline Glutamate & + & - \\
\hline Malonate & + & - \\
\hline L_Ornithine & + & - \\
\hline L-Leucine & - & - \\
\hline
\end{tabular}


Biodegradation of anionic surfactants by isolated bacteria...

Table 2: Results of HPLC analysis depends on concentration and removal percentage of SDS from culture

\begin{tabular}{|c|c|c|c|c|c|c|}
\hline \multicolumn{3}{|c|}{ Co- culture } & \multicolumn{2}{|c|}{ A isolate } & \multicolumn{2}{|c|}{ B isolate } \\
\hline Incubation period & LABS level & Utilization & LABS level & Utilization & LABS level & Utilization LABS \\
\hline (day) & $(g / L)$ & LABS (\%) & (g/l) & LABS (\%) & $(g / L)$ & (\%) \\
\hline 0 & 0.500 & 00.0 & 0.500 & 00.0 & 0.500 & 00.0 \\
\hline 3 & 0.236 & 52.8 & 0.341 & 31.8 & 0.350 & 30.0 \\
\hline 5 & 0.035 & 93.1 & 0.077 & 84.6 & 0.032 & 93.6 \\
\hline 7 & 0.016 & 96.8 & 0.018 & 96.4 & 0.025 & 95.0 \\
\hline
\end{tabular}

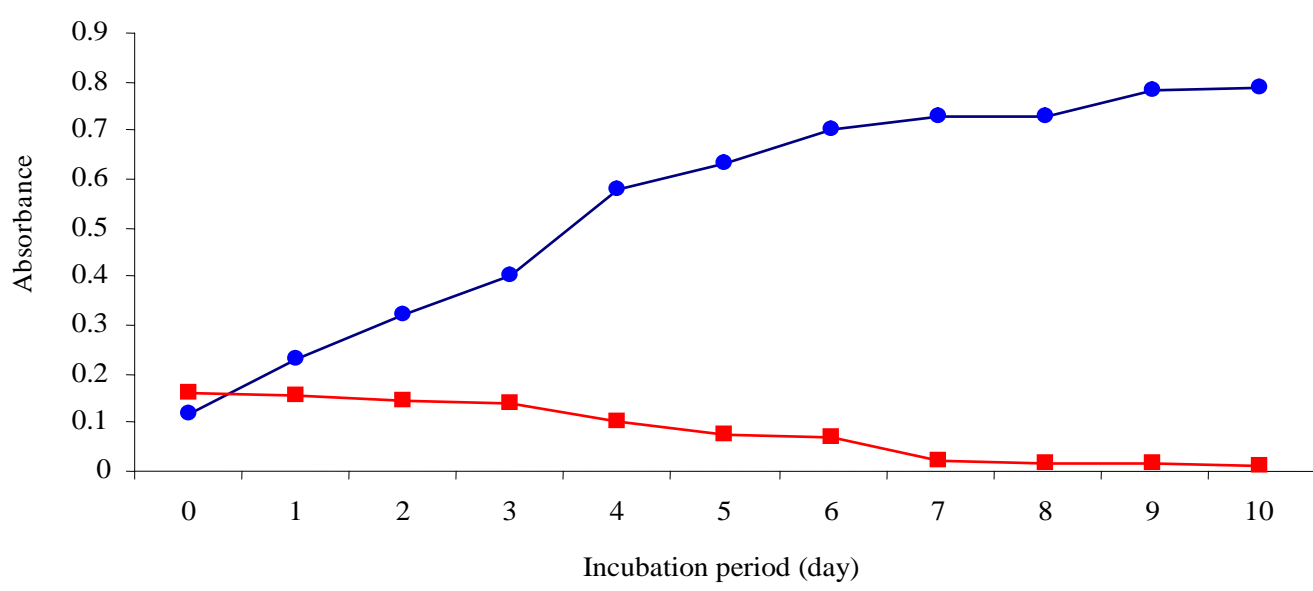

$\longrightarrow$ O.D. $\quad \longrightarrow$ SDS (g/L)

Fig. 3: Growth of A strain in relation to SDS degradation

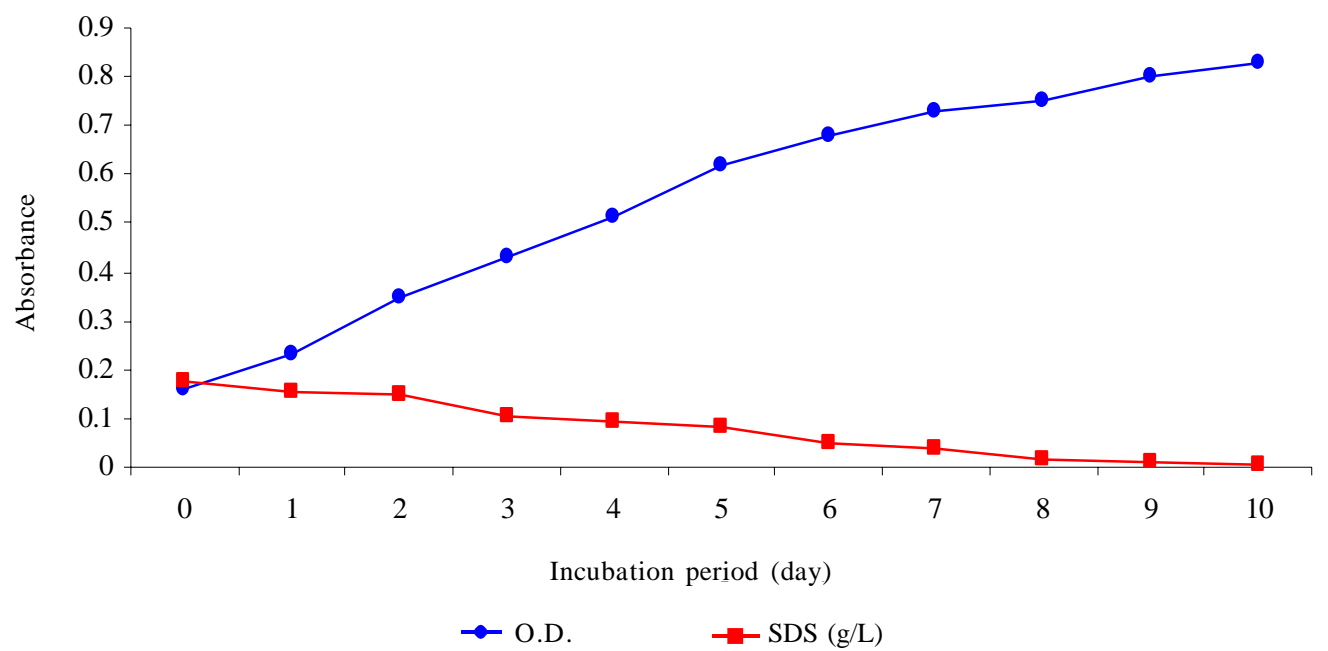

Fig. 4: Growth of B strain in relation to SDS degradationz 


\section{DISCUSSION AND CONCLUSION}

Past experiences have demonstrated those anionic surfactants biodegradations are exclusively conducted by bacteria (Cain, et al., 1981 and Juker, et al., 1994). Investigators such as Schleheck, et al., 2000, Jimenez, et al., 1991 and Dhuiib, et al., 2003, have used activated sludge cultures in order to isolate heterotrophic anionic surfactant degrading bacteria. In this survey, aerobic cultures of activated sludge from Tehran municipality were performed in order to isolate anionic surfactant degrading bacteria. Two different bacteria were isolated after subsequent growth in basal salt media containing SDS as the sole carbon and energy source. Schleheck, et al, 2003, have used 16S rRNA gene sequencing for surfactant degrading bacteria identification. Whereas, Dhuib, et al., 2003, have relied solely on biochemical tests in order to identify their isolated bacteria. In this survey, we have used both biochemical as well as molecular methods in order to identify the two strains. The maximum is in agreement with the observation of Dhuib, et al, 2003, and Schleheck, et al., 2000. Hyashi, et al., 1975, have used methylene-blue activated substances (MBAS) method for determination of anionic surfactant biodegradation in aquatic environments. This chromatographic method was originally proposed in 1976 and was subsequently used by many other investigators (Kertesz, et al., 1994, Jerabkova, et al., 1999, and Dhuib, et al, 2003). Jerebkova, et al., 1999, have used this technique to valuate anionic surfactant elimination by Pseudomonas biofilms. In later years, Schleheck, et al, 2000, and Schulz et al., 2000, have suggested that the presence of contaminating ions and intermediate compounds can inhibit precise detection of SDS levels by the methylene- blue assay. They suggested that HPLC is a superior technique for SDS identification. Continued growth and biomass accumulation of the bacteria were coincidental in the via. This indicates that the bacteria are actually utilizing SDS as their sole carbon source. This is in agreement with the results of other investigators (Di Cocia et al., 1994, Jimenez et al., 1991, and Sigoillot et al., 1992). During stationary phase, (7 $7^{\text {th }}$ till $10^{\text {th }}$ days of growth), no significant decrease in SDS levels was detected, indicating that bacterial growth had begun to level off. This was true for both A and B strains. Jerebkova et al., 1999, have noted that Pseudomonas cultures in continuous bioreactors have contributed to a $70 \%$ decrease in surfactant levels after 20 days. Other studies have noted different levels of surfactant utilization in closed cultures. For instance, over $90 \%$ of surfactant usage was noted by locally isolated Citrobacter spp. after 35 hours of growth (Schleheck et al., 2003). In this survey, the B strain was able to utilize $94 \%$ of the original SDS levels after 120 hours. The biodegradation rate was the highest between 3 and 5 days. Sigoillot et al., 1992, have reported that mixed cultures of different bacteria can dramatically improve the biodegradation potential. In this study, co-culture of the two isolated strains did not cause a dramatic rise in surfactant utilization.

The obtained results shown that anionic surfactants significantly biodegraded by bacteria. The results of this study suggest that growth of simple bacteria such as Acinetobacter or Pseudomonas in household and industrial sewage can be a cost-effective method of anionic surfactant elimination.

\section{REFERENCES}

Cain, R.B., (1981). Microbial degrading of surfactants and builder components in microbial degradation of xenobiotics and recalcitrant compounds. In, The prokaryotes., (Balows, H. Truper, M. and Dworkin, W., Eds.), Springer-Verlag, Berlin, Germany. 2625-2637.

Dhuiib, A., Hamad, N., Hassairi I., (2003) Degradation of anionic surfactants by Citrobacter braakii. Proc. Biochem., 38, 1245-1250.

Di Corcia, A., Samperi, R., Marcomini, A., (1994) Monitoring aromatic surfactants and their biodegradation intermediates in raw and treated sewages by solid-phase extraction and liquid chromatography. Environ. Sci. Technol., 28, 850858.

Eichhorn, P., Rodriguez, S.V., Baumann, W., Knepper, T., (2002). Incomplete degradation of SDS in Brazilian surface waters and pursuit of their polar metabolites in drinking waters., Sci. Environ., 284, 123-134.

Hayashi, K., (1975). A rapid determination of sodium dodecyl sulfate with methylene blue., Anal. Biochem., 67, 503-506.

Jerabkova, H., Blanka, K. and Nahlik, J., (1999). Biofilm of Pseudomonas C12B on glass support as catalytic agent for continuous SDS removal., Int. Biodeteriorat. Biodegradat., 44, 233-241.

Jimenez, L., Breen, A., Thomas, N., (1991). Mineralization of linear alkylbenzene sulfonate by a four-member aerobic bacterial consortium., Appl. Environ. Microbiol., 57, 15661569.

Juker, F., Leisinger, T., Cook, A.M., (1994). 3-Sulphocatechol 2,3dioxygenase and others in the degradative pathways of 2-aminobenzenesulphonic and 4-toluenesulphonic acids in Alcaligenes SP. Microbiol., 140, 1713-1722.

Kertesz, A., Kolbener, P., Stockinger, H., Beil, S., (1994) Desulfonation of linear alkylbenzene sulfonate and related compounds by bacteria., Appl. Environ. Microbiol., 60, 2296-2303.

Laue, I.I., Field, J.A., Cook, A.M., (1996). Bacterial disulfonation of the ethanesulfonate metabolite of the choloracetanilide herbicide metazachlor., Environ. Sci. 


\section{F. Hosseini, et al.}

Technol., 30, 1129-1132.

Schleheck, D., Dong, W., Denger, K., (2000). An Alphaproteobacterium converts linear alkylbenzenesulfonate into sulfophenylcarboxylates and linear alkyldiphenyletherdisulfonate surfactants into sulfodiphenylethercarboxylates., Appl. Environ. Microb., 66, 1911-1916.

Schleheck, D., Lechner, M., Schonenberger, R., (2003). Desulfonation of the disufodiphenylethercarboxylates from alkyldiphenyletherdisulfonate surfactants., Appl. Environ. Microb., 69, 938-944.
Schulz, S., Dong, U., (2000). Enantimeric degradation of 2-, (4-sulfophenyl) butyrate via 4-sulfocatechol in Delftia acidovorance SPB1., Appl. Environ. Microb., 66, 19051910.

Sigoillot, J.C., Nguyen, M., (1992). Complete oxidation of linear alkyl benzene sulfonate bacterial communities selected from coastal seawater., Appl. Environ. Microb., 58, 13081312.

Sigoillot, J.C., Nguyen, M., (1990). Isolation and characterization of surfactants degrading bacteria in a marine environment., FEMS Microbol. Ecol., 73, 59-68.

\section{AUTHOR (S) BIOSKETCHES}

Hosseini, F., is a Ph.D. student, Department of Microbiology, Science and Research Campus, Islamic Azad University, Tehran, Iran. Email: farzaneh953@yahoo.com

Malekzadeh, F., is professor at the Department of Microbiology, Science and Research Campus, Islamic Azad University, Tehran, Iran. Email: falmero@yahoo.com

Amirmozafari N., is professor of Department of Microbiology, Iran University of Medical Sciences, Tehran, Iran. E-mail: amirmozafari@yahoo.com

Ghaemi, N., is professor of Department of Biotechnology, Tehran University, Tehran, Iran.

Email: nasser.ghaemi@khayam.ut.ac.ir

This article should be referenced as follows:

Hosseini, F., Malekzadeh, F., Amirmozafari N., Ghaemi, N., (2007). Biodegradation of anionic surfactants

by isolated bacteria from activated sludge. Int. J. Environ. Sci. Tech., 4 (1), 127-132. 